\title{
Lament nad światem. 0 ludzkiej godności, nierównościach i niepokojach społecznych w kinie najnowszym
}

\begin{abstract}
Streszczenie
Przedmiot rozważań stanowią wybrane filmy ilustrujące społeczne nierówności i wynikające $\mathrm{z}$ nich niepokoje w różnych częściach świata na przełomie drugiej i trzeciej dekady XXI wieku. Ich bohaterowie pozbawieni możliwości edukacji, pracy, opieki medycznej i godnego miejsca do mieszkania żyją bez nadziei na poprawę egzystencji. Narastająca frustracja prowadzi do agresji, łamania prawa, brutalnej przemocy oraz zamieszek i walk ulicznych. Celem artykułu jest namysł nad problematyką podejmowaną w filmowych dyskursach i próba znalezienia odpowiedzi na pytania o przyczyny i czynniki wywołujące społeczne niepokoje. Do analizy badanej problematyki została wykorzystana kategoria godności ludzkiej.
\end{abstract}

\section{Słowa kluczowe:}

film, godność ludzka, niepokoje społeczne, nierówności społeczne

\section{Abstract}

The subject-matter of my consideration covers chosen films about social inequalities and the resulting unrest in various parts of the world at the turn of the second and third decade of the 21st century. Film characters

1 Ewelina Konieczna, Wydział Sztuki i Nauk o Edukacji, Uniwersytet Śląski w Katowicach, Polska, e-mail: ewelina.konieczna@us.edu.pl, ORCID ID: https://orcid.org/0000-0002-8042-3956. 
deprived of education, work, medical care and a dignified place to live have no hope of improving their existence. Growing frustration leads to aggression, breaking the law, brutal violence as well as riots and street fights. The purpose of this article is to reflect on the issues raised in film discourses and to try to find answers to questions about the causes and factors that cause social unrest. The category of human dignity was used to analysis the studied issues.

\section{Keywords:}

film, human dignity, social unrest, social inequality

\section{WPROWADZENIE}

Bohaterami naszych czasów są Jokery, pasożyty i nędznicy siejący zniszczenie. Filmy karmią się atmosferą, która ogarnia świat, a ich bohaterowie nie chcą już nikogo zbawiać. Wykluczeni społecznie i ekonomicznie frustraci biorą odwet za doznane krzywdy, a napędza ich pogarda zamożnej części społeczeństwa, poczucie utraty wartości i godności oraz arogancja i cynizm polityków. Polityczna rzeczywistość i rozmaite formy wykluczenia prowokują do buntu, budzą sprzeciw i żądzę destrukcji niesprawiedliwego świata. Systematycznie pozbawiani możliwości edukacji, pracy, opieki medycznej, mieszkają w ponurych norach lub na ulicy bez nadziei na poprawę egzystencji. Filmy o społecznych desperatach takie jak zdobywca Złotej Palmy w Cannes oraz nagrodzony Oscarem w kategorii najlepszy film międzynarodowy południowokoreański Parasite (2019, reż. Bong Joon-ho) czy amerykański Joker (2019, reż. Todd Philips), laureat Złotego Lwa na Międzynarodowym Festiwalu Filmowym w Wenecji (oraz Złotych Globów, Nagrody BAFTA i Oscarów za muzykę i najlepszą rolę męską) mogą liczyć zarówno na globalną widownię, jak i artystyczne uznanie. Francuski film Nędznicy (Les Miserables, 2019, reż. Ladj Ly) zdobył Nagrodę Jury na Festiwalu Filmowym w Cannes, otrzymał Europejską Nagrodę Filmową w kategorii „Odkrycia” oraz był nominowany do Oskara w tej samej kategorii co Parasite. Przedmiotem mojego szkicu są trzy filmy z 2019 roku, ilustrujące społeczne nastroje i niepokoje w różnych częściach świata na przełomie drugiej i trzeciej dekady XXI wieku. Namysł nad problematyką podejmowaną w filmowych dyskursach skłania do sformułowania wielu pytań, ale odpowiedzi nie będą ani łatwe, ani zadowalające. Kim są bohaterowie filmów? Skąd bierze się ich gniew? Dlaczego uciekają się do przemocy? Jakie są ich motywacje do podejmowania destrukcyjnych działań? Czy działania te są wyrazem niezadowolenia i frustracji wynikającej z braku 
poszanowania godności bohaterów? Czy i dlaczego działania bohaterów są przejawem nieposłuszeństwa obywatelskiego i czy mają jakąkolwiek siłę sprawczą prowadzącą do zmiany społecznej? Dlaczego twórcy podejmują taką tematykę? Czy i dlaczego filmy te są odbiciem społecznych nastrojów? Jakie jest społeczne oddziaływanie tychże filmów? W niniejszym artykule spróbuję choć po części znaleźć odpowiedzi na nurtujące mnie pytania, w czym pomocne będzie spojrzenie na badaną problematykę przez pryzmat pojęcia godności ludzkiej.

\section{GODNOŚĆ CZŁOWIEKA}

Choć kategoria godności ma długą tradycję, to „nie istnieje żadne ogólnie i powszechnie przyjęte »kanoniczne« pojęcie godności ludzkiej” (Żełaniec 2012, s. 9). Pojawia się ono już w czasach starożytnych jako godność ludzka, godność człowieka, przysługująca każdemu człowiekowi bez względu na jego cechy. Pojęcie godności osobistej powiązane było z doskonałością w dążeniu do wartości, przestrzeganiem zasad moralnych oraz osobistymi zasługami; godność osobista była wyżej ceniona niż niczym niezasłużona godność ludzka. Obecnie godność jest analizowana jako godność osobowa, godność osobowościowa, poczucie godności oraz godność społeczna. (Olbrycht 2019, s. 211). Godność istoty ludzkiej sytuuje się wśród pojęć o charakterze interdyscyplinarnym. W filozofii chrześcijańskiej godność człowieka wynika ze stworzenia człowieka na podobieństwo Boga (Garlicki 2000, s. 90). „Godność osobowa wyraża fakt najwyższej wartościowości człowieczeństwa jako takiego, bezwzględnej wartości każdego człowieka, która przysługuje mu bezwarunkowo. W filozofii chrześcijańskiej podkreśla się, iż wartość ta jest przyrodzona człowiekowi jako istocie cielesno-duchowej. Według K. Wojtyły godność osoby ludzkiej zakorzeniona jest w zdolności człowieka do samostanowienia i transcendencji. (...) Godność człowieka jako osoby jest podstawą wszelkich praw człowieka, które są chronione licznymi dokumentami o randze międzynarodowej” (Olbrycht 2019, s. 211). We współczesnej etyce obecne są dwa podstawowe znaczenia kategorii godności: godność ludzka jako niezbywalna wartość przysługująca każdemu bez wyjątku człowiekowi oraz godność osobista traktowana jako szczególna właściwość jednostki ludzkiej, która może występować w powiązaniu z rolą społeczną. Prowadzi to do wyróżnienia dwóch koncepcji godności - godności osobowej (aksjologiczno-ontycznej) i godności osobowościowej (empirycznej). Zgodnie z pierwszą koncepcją godność rozumiana jest jako wartość wrodzona, która przysługuje człowiekowi z racji tego, że człowiek jest istotą rozumną, wolną i opatrzoną sumieniem, dlatego jego 
godność jest wartością trwałą, niezbywalną i powszechną. Godność osobowościowa stanowi doskonałość ukształtowaną na drodze moralnie wartościowego działania i utrwaloną w charakterze jednostki, jest właściwością człowieka, ale nie przysługuje mu bezwarunkowo. Można ją osiągnąć przez wychowanie, pracę nad swoim rozwojem, a także przez oddziaływanie środowiska społecznego. Tak rozumiana godność nie jest wartością wrodzoną i stałą, ale łączy się z dobrym imieniem, dobrą sławą, szacunkiem, honorem, gotowością do poświęcenia się i obrony uznawanych wartości (Ossowska 1969, s. 8). Jednakże warto zwrócić uwagę, że w rozumieniu personalistycznym „tak jak nieutracalna jest godność osobowa, tak godność osobowościowa, własna może ulec osłabieniu, jeśli człowiek nie respektuje godności osobowej. Nie traci godności ktoś, kto jest poniżany jako człowiek, lecz ten kto poniża” (Olbrycht 2019, s. 211). Poczucie godności natomiast lub inaczej godność osobista to godność rozumiana jako „dobre imię”, jest świadomością własnej godności wyrosłą z potrzeby uznania jej przez innych. „Może być ona nabywana, naruszana i tracona zarówno przez własne działania, jak i przez działania innych podmiotów” (Mrozek 2014, s. 44).

Zagadnienie godności osoby ludzkiej, wcześniej stanowiące margines filozoficznej i naukowej refleksji, trwale uobecniło się w refleksji naukowej i publicystycznej po II wojnie światowej i proces zainteresowania nim trwa do dnia dzisiejszego, co nazwane zostało przez Jonasa Totha „rewolucją godności ludzkiej (revolution of human dignity)" (Buller 2012, s. 52). Także w licznych dokumentach międzynarodowych - konstytucjach państw oraz innych dokumentach instytucji i organizacji społecznych godność osoby ludzkiej znajduje się na ważnym miejscu. „W Powszechnej Deklaracji Praw Człowieka (1948) termin godność osoby ludzkiej pojawia się pięciokrotnie w następujących odmianach: godność przyrodzona, godność i wartość osoby ludzkiej, godność, ludzka godność i jego (człowieka LJB) godność. We wspomnianym dokumencie termin godność osoby ludzkiej jest rozumiany w następujący sposób: »jest to godność przyrodzona, właściwa każdemu człowiekowi jako istocie ludzkiej, którą każdy przynosi na ten świat wraz ze swym urodzeniem «. W Międzynarodowych Paktach Praw Człowieka, jak i Akcie Końcowym z Helsinek (KBWE) - godność osoby ludzkiej uznano za podstawę praw człowieka, gdyż wynikają one z niej i ją chronią” (Buller 2012, s. 52).

Istnieje jeszcze kategoria godności społecznej rozumianej jako ogół działań na rzecz poszanowania godności indywidualnej. Rozumienie to wynika z etyki kantowskiej zakładającej, że godność jest rodzajem moralnej wartości osoby, zapewniającej jej prawo do szacunku (Walker 2011, s. 163). Tak definiowana godność społeczna jest tożsama z kategorią godności życia, którego poziom można badać i oceniać, „wskazując, czy sytuacja bytowa, relacje społeczne i inne ele- 
menty funkcjonowania jednostki w społeczeństwie cechują się poszanowaniem lub brakiem szacunku dla godności indywidualnej” (Sadowy 2014, s. 67).

\section{JOKER, CZYLI GODNOŚĆ POGWAŁCONA}

Kino społecznie zaangażowane, doraźne, interwencyjne ukazujące mechanizmy społecznego rozwarstwienia nie przynależy wyłącznie do obszaru kina artystycznego. Hollywoodzki film Joker ukazuje frustrację ludzi wykluczonych przez system, rejestruje nastroje społeczne i ich mroczne konsekwencje. Komiksowa postać, późniejszy wróg Batmana staje się nośnikiem cech ludzi usuniętych na obrzeża społeczeństwa, bez szansy na rozwój, powodzenie, szczęście, skazanych na porażkę i upadek, bo przekonanych o swej bezwartościowości przez ciągłe naruszanie ich godności. Arthur Fleck, grany przez Joaquina Phoenixa, jest nieudolnym komikiem, który nieustannie ponosi porażki. Cierpi na przypadłość objawiającą się niepohamowanym, demonicznym śmiechem, który pojawia się w najmniej spodziewanych momentach. Po wyjściu ze szpitala psychiatrycznego nie znajduje odpowiedniej pomocy medycznej i społecznej. Wydaje się, że cały świat stanął przeciwko niemu - apodyktyczna matka, z którą ciągle mieszka, obojętna i niekompetentna terapeutka, dokuczający nieudacznikowi koledzy z pracy, znęcający się nad nim uliczni chuligani. Przez jakiś czas próbuje bez powodzenia swych sił w stand-upie, marząc o staniu się telewizyjną gwiazdą. Kiedy okazuje się to niemożliwe, zaczyna pracować jako klaun, reklamujący bary i zabawiający dzieci w szpitalach. Ale i tę pracę traci. Żyje w zaśmieconej, brudnej rzeczywistości w umownych realiach lat 80. XX wieku. Zapożyczone z komiksu o Batmanie Gotham City jest miastem przemocy i strachu, piekielną metropolią, która składa się z zepchniętych na margines, wykluczonych godnościowo i społecznie jednostek. Początkowa nieporadność bohatera przekształca się w wolę destrukcyjnego działania. Warunki społeczne, które doprowadziły do życiowego i moralnego upadku, zmuszają go do łamania prawa. Przemoc i zbrodnia jako odwet na cynicznym, bogatym społeczeństwie zyskuje akceptację podobnie doświadczonych biedą i pogardą społeczną oraz staje się orężem w walce ze złem, które spotkało ich ze strony uprzywilejowanych. Obraz zamieszek przypomina te, które mają miejsce w różnych regionach współczesnego świata, co czyni z filmu przejmującą krytykę naszej rzeczywistości społecznej, systemów politycznych, bezwzględnego kapitalizmu, a także mediów żerujących na nieszczęściu słabszych członków społeczeństwa, sukcesywnie pozbawianych społecznej godności. 
Marne warunki bytowe, brak lub ograniczony dostęp do opieki medycznej, bezrobocie, bezdomność obniżają i niszczą godność życia jednostek oraz są wyrazem braku poszanowania władzy (państwa, systemu) dla godności osobistej człowieka. Zatem jeżeli państwo nie szanuje bezwarunkowej wartości wewnętrznej człowieka, czyli jego godności, dopuszcza się (w rozumienia Kanta) złamania obowiązku, zasady moralności, a tym samym prawa. Państwo dla Kanta to „systematyczne powiązanie różnych rozumnych istot przez wspólne prawa. A ponieważ prawa określają cele wedle ich powszechnego obowiązywania (...) to całość wszystkich celów (...) da się pomyśleć w systematycznym związku, tj. jako państwo celów” (Kant 1984, s. 68-69). Pisząc o państwie celów, Kant zwraca uwagę na konieczność postępowania według obowiązku, który ciąży w równej mierze na każdym członku państwa, ale nie jest celem samym w sobie. „W państwie celów wszystko ma albo jakąś cenę albo godność. To, co ma cenę, można zastąpić także przez coś innego, jako jego równoważnik, co zaś tę cenę przewyższa, a więc nie dopuszcza żadnego równoważnika, posiada godność” (Kant 1984, s. 70-71). Tak rozumiana idea godności posiada bezwarunkową wartość wewnętrzną i w przeciwieństwie do ceny może być celem samym w sobie.

Łamanie prawa przez zrozpaczonych i gniewnych bohaterów jest wynikiem łamania prawa przez państwo, które nie wypełnia swych obowiązków wobec obywateli. Jest reakcją na doświadczane zło i niesprawiedliwość. Oczywiście świat przedstawiony w filmie nie jest światem realnym, ale pozwala na dokonanie spostrzeżeń i refleksji na temat źródeł i konsekwencji wykluczenia godnościowego jednostek i całych grup społecznych.

Interesującym wątkiem jest odwołanie do Charliego Chaplina i jego Dzisiejszych czasów (Modern Times, 1936) filmu, którego fragmenty Todd Philips wykorzystuje w znamiennej scenie, kiedy siedząca w kinie elita śmieje się do rozpuku, oglądając satyrę na bezwzględny kapitalizm i wyzyskujący ludzi system polityczny. Film zrealizowany podczas Wielkiego Kryzysu w pierwszej połowie XX wieku odnosi się do problemów społecznych, z jakimi borykała się wtedy Ameryka - bezrobocia, nędzy, głodu - i jest krytyką kapitalizmu oraz nierówności społecznych. Chaplin zagrał proletariusza, który aby przeżyć, zmuszony jest walczyć z nieludzkim systemem i różnymi instytucjami społecznymi (Plesnar, 2011, s. 129). Zacytowana w Jokerze scena sugeruje, że na początku XXI wieku niewiele się na świecie zmieniło.

Joker opowiada o narodzinach zła, którego źródło leży w krzywdzie ludzi, wyzysku, bezdusznym systemie, wyrzucającym słabe jednostki na margines społeczeństwa. Film ukazuje przyczyny przemiany Arthura Flecka z wykluczonej społecznie i godnościowo jednostki w późniejszego przeciwnika Mrocznego Ry- 
cerza - Jokera, upiorną postać z komiksu, będącą ucieleśnieniem zła. Todd Philips w zakończeniu filmu pokazuje prawdę o rzeczywistości - jego bohater nie jest sam; takich jak on, pełnych gniewu i żądzy odwetu na społecznych elitach jest wielu, zbyt wielu, by można było ich nie zauważyć. Frustracja wykluczonych przemienia się w filmie we wściekłość i furię prowadzącą do niekontrolowanej przemocy.

\section{PASOŻYTY W SPOŁECZEŃSTWIE DOBROBYTU}

Bong Joon-ho w filmie Parasite tworzy portret współczesnego społeczeństwa koreańskiego, wykorzystując schematy kina gatunkowego. Interesuje go (podobnie jak we wcześniej zrealizowanych filmach) problem tożsamości Koreańczyków, źródła ich traum, frustracji i społecznych nierówności. Polaryzacja ekonomiczna, różnice klasowe, podział na biednych i bogatych to temat aktualny i uniwersalny. Film pomyślany jako satyra jest opowieścią o tym, jak biedna rodzina została zmuszona do pasożytowania na bogatej. Rodzice są bez szans na zdobycie dobrze płatnej pracy, córka i syn nie mają możliwości studiowania w prestiżowych uczelniach. Ta zwyczajna czteroosobowa rodzina zepchnięta na społeczny margines mieszka razem z karaluchami w ciemnej, zatęchłej suterenie. Mieszkańcy piwnicy widzą ludzi załatwiających swe potrzeby fizjologiczne bezpośrednio pod ich oknem. Podczas ulewnego deszczu ten cuchnący świat dosłownie wlewa się do ich życia. Deszczówka wymieszana z fekaliami zalewa ich godność. Metaforyczne szambo wypełnia codzienność, z której za wszelką cenę próbują uciec. Najpierw syn dostaje możliwość udzielania korepetycji z języka angielskiego nastolatce z klasy uprzywilejowanej, potem reszta rodziny, po serii kłamstw i fałszerstw dokumentów, potwierdzających ich wykształcenie i kompetencje, zaczyna pracować dla zamożnych ludzi. Córka zostaje nauczycielką plastyki młodszego dziecka, matka pomocą domową, ojciec kierowcą. Dwie rodziny wzajemnie na sobie żerujące - biedna pracująca dla bogatej oraz bogata korzystająca z usług biednej - spotykają się w przestronnym ekskluzywnym wnętrzu, które staje się sceną filmowego dramatu.

Dwa domy - cuchnąca suterena i luksusowa willa z bunkrem (zbudowanym na wpadek inwazji Korei Północnej) tworzą symboliczne przestrzenie społecznych nierówności. Świat podzielony na przegranych i tych, którym się udało. Tych, którzy muszą walczyć o własną godność i tych, którzy ją tracą, pozbawiając jej innych. Mimo że członkowie ubogiej rodziny dopuszczają się oszustw i przemocy, to sympatia widzów leży po ich stronie - bohaterowie walczący o przetrwanie budzą empatię. Reżyser pokazuje rozgrywającą się w zamkniętej przestrzeni 
willi potyczkę pomiędzy dwiema drużynami - biedną i bogatą. W ostatecznym rozrachunku tragedia spotyka wszystkich, nie ma wygranych. Ludzie z różnych warstw społecznych nie mogą znaleźć wspólnego języka, nie rozumieją swoich problemów. Przepaść się pogłębia, za co odpowiedzialne jest coraz większe bezrobocie w Korei Południowej. Wszyscy członkowie biednej rodziny są zdolni do pracy, mają rozmaite talenty, ale nikt nie może w legalny sposób znaleźć zatrudnienia, bo jak mówi w jednej ze scen pan Park, ojciec rodziny: „na jedną posadę ochroniarza przypada pięciuset absolwentów college'u”.

To, co różni obie warstwy społeczne, to zapach, który twórca filmu czyni istotnym elementem narracji. Ubodzy, żyjący na marginesie społeczeństwa pachną inaczej, zapach jest znakiem rozpoznawczym obcego, intruza w bezpiecznym świecie ekonomicznych elit. Biedni rozsiewają zapach stęchlizny, gnicia, obumarłej materii. Zapach ten budzi niepokój i poczucie zagrożenia żyjących w luksusie i pozbawionych trosk o codzienny byt ludzi. Dziwny, inny zapach demaskuje mieszkańców zalanej szambem sutereny, to dzięki niemu bogacze odkrywają, że korepetytorzy ich dzieci, pomoc domowa, szofer są jedną rodziną i stanowią dla nich zagrożenie. Zapach jako metafora społecznych różnic i podziałów po prostu drażni i przeszkadza. Można go unikać, ale problem pozostaje. I cuchnie.

Opowiadający przejmującą historię i trzymający w napięciu jak thriller Parasite zachwycił nie tylko jurorów Festiwalu Filmowego w Cannes i członków Amerykańskiej Akademii Filmowej, ale także publiczność gustującą w kinie gatunkowym, co sytuuje go, podobnie jak hollwoodzki film Joker, na styku kina artystycznego i popularnego. I tak jak film Todda Philipsa pokazuje, że zło i przemoc mają swe korzenie w godnościowym, społecznym i ekonomicznym wykluczeniu. Film Bonga Joon-ho jest opisem konkretnej rzeczywistości, a punkt wyjścia filmowej opowieści stanowią realia i nastroje społeczne, frustracja części społeczeństwa, żyjącego w państwie dobrobytu, ale bez dostępu do większości dóbr. Bohaterowie filmu to ludzie odsunięci od możliwości korzystania z podstawowych praw: do pracy, edukacji, opieki medycznej i godnego mieszkania, spychani na margines, tracący poczucie własnej wartości i godności osobistej oraz społecznej. Warunki, w jakich żyją, brak legalnych perspektyw na poprawę losu, powodują, że uciekają się do fałszerstw, przemocy i zbrodni. Parasite jest satyrą wymierzoną w zachłanny establishment i współczesny świat, w którym pogłębiają się procesy prowadzące do wykluczenia ekonomicznego; stanowi przypadek kina zaangażowanego społecznie, którego celem jest zwrócenie uwagi na niesprawiedliwość i konsekwencje społecznych podziałów. 


\section{NĘDZNICY Z PRZEDMIEŚĆ - SYGNAŁ OSTRZEGAWCZY}

Tytuł filmu Nędznicy nawiązuje do XIX-wiecznej powieści Victora Hugo; Ladj Ly - francuski reżyser o malijskich korzeniach pierwotnie myślał o jej filmowej adaptacji. Jednakże brutalna interwencja policji w czasie rozruchów na przedmieściach w 2005 roku, której był świadkiem, skłoniła go do wykorzystania tych wydarzeń najpierw w filmie krótkometrażowym z 2017 roku pod tym samym tytułem, a następnie rozwinięcia problemu w pełnym metrażu. W efekcie powstał poruszający i niepokojąco aktualny film, w dużej mierze autobiograficzny. Ladj Ly urodził się w Paryżu, ale wychował się w Montfermeil (miejscu, z którego pochodzą bohaterowie powieści Hugo), w zróżnicowanej etnicznie dzielnicy zamieszkanej przez imigrantów, gdzie konflikty i napięcia należały do codzienności. „Ten film jest rodzajem autobiografii - gdy jest się świadkiem czegoś i przebywa w samym środku tej sytuacji. Wszystko, co jest w nim zawarte, od początku do końca, ma inspiracje w moim życiu” - mówi reżyser (Ladj Ly, Armata, 2020 s. 31).

Montfermeil - dzielnica, z której wywodzą się bohaterowie filmu - jest współczesnym gettem zamieszkałym głównie przez imigrantów z Afryki Północnej. Film rozpoczyna sekwencja filmowana przez chłopca z dronem, ukazująca z ptasiej perspektywy blokowisko i jego mieszkańców. Oglądamy sceny poniżania ich przez policjantów oraz traktowania jak potencjalnych przestępców, co boleśnie uderza w poczucie godności własnej każdej w ten sposób traktowanej osoby. Dotyka to zwłaszcza młodych postrzeganych przez przedstawicieli władzy jako główne zagrożenie dla bezpieczeństwa publicznego. Doświadczanie świata przez pryzmat nędzy i niechęci ze strony rdzennych Francuzów, a przede wszystkim władzy, rodzi ból, gniew i agresję. Młodzi ludzie od wczesnego dzieciństwa czują się przegrani, bez szans na przyzwoitą edukację, a później pracę. Noszą w sobie ogromne poczucie krzywdy, które w sytuacji zagrożenia wybucha i prowadzi do brutalnej konfrontacji. Kiedy policjanci próbują odebrać jednemu z chłopców ukradzione z cyrku lwiątko, dochodzi do bójki, pada strzał. Kula rani małego złodzieja, a policjanci próbują zatuszować sprawę, gdy okazuje się, że całe wydarzenie przypadkowo zarejestrował chłopiec z dronem. Przepełnione gniewem i nienawiścią dzieci pragną zemsty, w stronę policji lecą kamienie i petardy.

Akcja filmu rozgrywa się w Paryżu latem 2018 roku podczas finału piłkarskich mistrzostw świata. Początkowo rdzenni Francuzi, imigranci i policjanci wspólnie świętują na Polach Elizejskich zwycięstwo Francji, które jest także udziałem francuskich piłkarzy pochodzących z Kamerunu i Gwinei. Pierwotne poczucie wspólnoty przeradza się we wzajemną wrogość różnych mniejszości etnicznych, młodzieżowe gangi zaczynają walczyć ze sobą, eksploduje złość, frustracja, 
nienawiść. W podsycaniu negatywnych emocji pomagają media elektroniczne i portale społecznościowe, za pomocą których młodzi się porozumiewają. Błahy żart prowadzi do konfrontacji społeczności Romów i Afrykanów, potem dołączają lokalni muzułmanie, następnie półświatek z dilerami narkotyków, a wszystko to dzieje się pod nadzorem policji, która jest w sojuszu z przywódcami lokalnych grup. Żywiołowe obrazy, częściowo dokumentalne, ruchliwa kamera, zdjęcia z ręki i z drona sytuują widza w centrum konfliktu i budują napięcie w oczekiwaniu na nieuchronną tragedię. Uczestnicy dramatycznych wydarzeń są tytułowymi nędznikami, nieustannie upokarzanymi i lekceważonymi, skazanymi na życiowe niepowodzenie. Film zwraca uwagę na brak poszanowania godności człowieka przez władzę i państwo, które dopuszcza się wobec swoich obywateli nie tylko złamania obowiązku i zasady moralności, ale także prawa (Kant, 1984, s. 68-69). Reżyser w emocjonalny, realistyczny sposób pokazuje konsekwencje ignorowania i wykluczenia całych grup społecznych, których frustracja i brak poczucia wartości oraz kwestionowanie ich osobistej i społecznej godności prowadzi, podobnie jak w Jokerze, do brutalnych zamieszek. Ponadto, tak jak w koreańskim Parasite, nie ma tutaj wygranych. Wszyscy członkowie społeczeństwa, niezależnie od przynależności społecznej, etnicznej i religijnej, przegrywają, kiedy w grę wchodzą brak wzajemnego szacunku, uprzedzenia, stereotypy, gniew, nienawiść do Innych. Rozejm, który kończy brutalny konflikt, jest dosyć wątpliwy i nie niesie nadziei na trwałą zmianę, czy poprawę relacji międzyludzkich, międzyetnicznych i międzykulturowych.

Ladj Ly swoim filmem nawołuje do wzięcia odpowiedzialności za tych, którzy zostali odsunięci na margines społeczny i pozbawieni zainteresowania ze strony rządzących oraz przestrzega przed ich narastającym gniewem. „Uważam, że Nędznicy to jeden z filmów, które powinny być rodzajem sygnału ostrzegawczego. Dla polityków, rządu, prezydenta Macrona. Wysłaliśmy mu zresztą wiadomość, że o ile wyrazi taka wolę, jesteśmy gotowi w każdej chwili przyjechać i pokazać mu film. Moim zdaniem powinien go zobaczyć, bo panuje tendencja do funkcjonowania we własnej strefie komfortu, przez co szybko zapominamy, jak wygląda prawdziwa rzeczywistość. Zwłaszcza politycy mają z tym problem, nie dostrzegając, jak zwykli ludzie potrafią cierpieć na co dzień. To trudny moment, bo być może jesteśmy w przededniu kolejnej rewolucji, której będziemy musieli stawić czoło. Tym razem przyjdzie ona właśnie z przedmieść, gdzie od dawna jest niespokojnie. Trzeba w końcu wziąć za to odpowiedzialność” (Ladj Ly, Armata, 2020, s. 32).

Nędznicy wpisują się również w nurt kina międzykulturowego i społecznie zaangażowanego. Przez ukazywanie konfliktów i trudnych relacji w wielokulturowych społeczeństwach kino to ma na celu uwrażliwiać widzów na problemy, które 
spychane dziś na dalszy plan mogą w niedalekiej przyszłości eksplodować z siłą, jakiej sobie nie wyobrażamy. Liczne w światowym kinie opowieści o migrantach, uchodźcach czy mniejszościach etnicznych skłaniają do refleksji nad problemami występującymi w wielokulturowych społeczeństwach oraz nad konsekwencjami kryzysu migracyjnego, wiążącego się z niewyobrażalnym cierpieniem ludzi oraz ich godnościowym wykluczeniem. Bogate i syte społeczeństwo zachodniego świata wydaje się nie zauważać ogromu cierpienia i nędzy do czasu, kiedy samo nie zostanie nim dotknięte. Film Ladj Ly mówi o utopii wielokulturowego społeczeństwa, gdzie ani asymilacja oparta na uznaniu inności, ani integracja ze społeczeństwem nowego kraju nie jest na razie możliwa. Istotą społeczeństwa wielokulturowego jest umiejętność przejścia od często wrogiej reakcji na inność do interakcji, czyli próby poznania, zrozumienia, współpracy i dialogu, ale „wizja społeczeństwa wielokulturowego przeżywa poważny kryzys, zwłaszcza w kontekście wykreowanej w cywilizacji Zachodu i kształtowanej tam idei relatywizmu kulturowego i poprawności politycznej, która w efekcie prowadzi do wykluczenia tożsamościowego i marginalizacji nie tylko imigrantów, ale także obywateli kraju ich przyjmującego" (Nikitorowicz, 2011, s. 18).

\section{PODSUMOWANIE}

Rozpatrując rozmaite sposoby pojmowania godności ludzkiej, Wojciech Żełaniec zauważa, że „dla całego piśmiennictwa poświęconego w jakimkolwiek stopniu problematyce godności ludzkiej charakterystyczne jest to, że na jedną wzmiankę o godności w sensie pozytywnym (czym ona jest, w czym się ona przejawia) przypada wiele wzmianek o godności ludzkiej w sensie negatywnym (kiedy jest gwałcona, kiedy dzieje się jej ujma itp.)” (Żełaniec, 2012, s. 14). Podobnie dzieje się w omawianych w tym szkicu filmach, które skupiają się właśnie na negatywnym sensie ludzkiej godności. Twórcy Jokera, Parasite i Nędzników sytuują swych bohaterów w krytycznych i granicznych sytuacjach oraz próbują zastanowić się nad czynnikami stanowiącymi zagrożenie dla poczucia godności człowieka i konsekwencjami godnościowego wykluczenia. Wybrane filmy pochodzą z różnych kontynentów - z Ameryki Północnej, Azji i Europy, powstały w tym samym roku i zostały nagrodzone prestiżowymi międzynarodowymi nagrodami filmowymi. Poruszają podobne problemy społeczne w uniwersalnych kontekstach, ale także kontekstach specyficznych dla kraju powstania. Joker luźno wykorzystuje bliską Amerykanom i powszechnie znaną konwencję popularnego komiksu o Batmanie i walce ze złem, pokazując jego genezę. Parasite odwołuje się do uniwersalnego 
problemu społecznych podziałów na biednych i bogatych oraz bezrobocia dotkliwie odczuwanego w Korei Południowej i na świecie; Nędznicy opowiadają o problemach wielokulturowej Francji, pogardzie dla imigrantów, a szerzej o nierozwiązanym kryzysie migracyjnym w Europie i na świecie.

Bohaterami filmów są jednostki z ograniczonymi przez warunki społeczne i system polityczny prawami do pracy, edukacji, opieki zdrowotnej i godnego miejsca do mieszkania. Ludzie wykluczeni ekonomicznie z racji przynależności klasowej czy etnicznej są spychani na margines, pozbawiani możliwości osobistego rozwoju, własnej wartości i godności. Ubóstwo i nędza, narastające poczucie niesprawiedliwości i krzywdy rodzą frustrację oraz lęk przed przyszłością, co staje się zarzewiem gniewu, prowadzącego do przemocy wobec zamożnej, silnej władzą części społeczeństwa. Dorośli, młodzież i dzieci nie mają nic do stracenia, a niezamierzona wcześniej brutalność i spontaniczna przemoc stają się celem samym w sobie, aktem sprzeciwu wobec biedy i sposobem zwrócenia uwagi na nierówności społeczne. Odsunięci na obrzeża społeczeństwa podejmują destrukcyjne i autodestrukcyjne działania, będące wyrazem niezadowolenia i frustracji, wynikającej z braku poszanowania ich godności osobistej i społecznej przez władzę oraz elity ekonomiczne. Łamanie prawa, zamieszki, walki uliczne, brutalna przemoc i zabójstwa stają się narzędziami walki z niesprawiedliwym systemem społecznym i politycznym. Twórcy filmów nie dają odpowiedzi na pytanie, czy agresywne działania bohaterów mają jakąkolwiek siłę sprawczą, która może doprowadzić do zmiany społecznej. Zakończenia filmów są otwarte i skłaniają do refleksji dotyczącej wizji przyszłego świata. Nie jest to jednak wizja optymistyczna. Filmy te są lamentem nad światem i rodzajem sygnału ostrzegawczego (jak mówił w cytowanym wywiadzie Lydj Ly), wołaniem o wzięcie odpowiedzialności za słabszą, żyjącą w nędzy i cierpiącą część społeczeństwa. Niektórzy filmowcy, tacy jak reżyser Nędzników, potomek imigrantów z Mali, doskonale znają nastroje społeczne grup, o których opowiadają. Odtwarzając realia, w jakich bohaterowie muszą codziennie zmagać się z niechęcią i wrogością, próbują nie tyle wzbudzić strach, ile uwrażliwić i nakłonić do wzięcia odpowiedzialności za ich los. Filmy te są odbiciem społecznych nastrojów, ale tylko jednej, tej pozbawianej godności i praw części społeczeństwa, ta druga, zamożna, siedzi na razie, tak jak w filmie Todda Philipsa, przed ekranem i śmieje się z perypetii proletariuszy z chaplinowskich Dzisiejszych czasów. 


\section{Bibliografia}

Buller, J.L. (2012). Godność osoby ludzkiej wymiarem podmiotowości człowieka w gospodarce. Annales: etyka w życiu gospodarczym, 15, s. 49-57.

Garlicki, L. (2000). Polskie prawo konstytucyjne. Zarys wykładu. Warszawa: Liber.

Kant, I. (1984). Uzasadnienie metafizyki moralności. Warszawa: PWN.

Mrozek, J.J. (2014). Godność osoby ludzkiej jako źródło praw człowieka i obywatela. Civitax et Lex, 1.

Nikitorowicz, J. (2011). Wykluczenie tożsamościowe w kreującym się społeczeństwie wielokulturowym wyzwaniem dla edukacji międzykulturowej - konteksty relatywizmu i poprawności politycznej. W: T. Lewowicki, A. Szczurek-Boruta, J. Suchodolska (red.), Pedagogika międzykulturowa wobec wykluczenia społecznego i edukacyjnego (s. 17-29). Cieszyn-Warszawa-Toruń: Wydawnictwo Adam Marszałek.

Olbrycht, K. (2019). Godność w teorii i praktyce wychowania. W: K. Olbrycht, Edukacja kulturalna jako edukacja do wzrastania w człowieczeństwie. Katowice: Wydawnictwo Uniwersytetu Śląskiego.

Ossowska, M. (1969). Normy moralne w obronie godności człowieka. Etyka, 5.

Plesnar, Ł. (2011). Hollywood: pod znakiem Wielkiego Kryzysu. W: T. Lubelski. I Sowińska, R. Syska (red.), Historia kina. T. 2. Kino klasyczne. Kraków: Universitas.

Sadowy, K. (2014). Godność życia jako miernik rozwoju społeczno-gospodarczego miast. Studia Regionalne i Lokalne, 1 (55).

Walker, M. (2011). Human dignity. W: C. Gastman, M. Verkerk (red.), Care, Compassion and Recognition: An Ethical Discussion. C. Leget, Walpole: MA: Peeters Publishers. Wziąć sprawy w swoje ręce. Z Ladjem Ly rozmawia Kuba Armata. (2020). Kino, 3.

Żełaniec, W. (2012). O pojmowaniu godności człowieka. W: M. Piechowiak, T. Turowski (red.), Szkice o godności człowieka (s. 7-20). Zielona Góra: Oficyna Wydawnicza Uniwersytetu Zielonogórskiego. 